\title{
CYMBELLA LOESCHERAE SP. NOV. (BACILLARIOPHYCEAE) FROM FIRST-ORDER STREAMS OF SOUTHERN BRAZIL
}

\author{
Marinês Garcia \& DÉBora Barwaldt Dutra
}

\begin{abstract}
This paper describes a new species of Cymbella C. Agardh from low-elevation countryside streams of the Serra do Sudeste, São Lourenço do Sul city, in southern Brazil. Cymbella loescherae M. Garcia \& D. B. Dutra $s p$. nov. has as distinctive features the elliptical shape of stigmata, elliptical internal areolae openings, and the presence of areolae of diverse shapes (X, I, Y, zig-zag) located mainly at the valve center on the dorsal and ventral sides. It resembles C. subhimalaspera Jüttner \& Van de Vijver which presents about the same metric data set, but differs from it primarily in the number and form of stigmata, and the form of areola internal openings.
\end{abstract}

Key words: Cymbella aspera group, diatom, freshwater, lotic habitat, new species, Rio Grande do Sul State, South America, taxonomy

Marinês Garcia \& Débora Barwaldt Dutra, Universidade Federal de Pelotas, Departamento de Botânica, Campus do Capão do Leão, CEP 96010-900, Pelotas, Rio Grande do Sul, Brazil; e-mail: marines@ufpel.edu.br

\section{INTRODUCTION}

Cymbella Agardh s.l. contains only freshwater species, distributed worldwide; the genus, especially the C. aspera group (Jüttner et al. 2010), is found living mainly in oligotrophic environments with bryophytes, or on moist sediments adjacent to streams. It includes more than 500 different species, not counting the different varieties (Fourtanier \& Kociolek 2011).

Large dorsiventral lanceolate Cymbella species with an apical axis ranging from 90 to $320 \mu \mathrm{m}$, width of $19 \mu \mathrm{m}$ or higher, with several small stigmata, and coarsely-punctate striae (5.5-14.0 areolae in $10 \mu \mathrm{m}$ ) are assembled in the C. aspera (Ehrenb.) H. Perag. group (Krammer 2002).

Van De Vijver and Lange-Bertalot (2008) and Jüttner et al. (2010) recognized other critical features in the $C$. aspera group, such as the morphology of external proximal raphe endings and the presence of areolae with distinct shapes such as $\mathrm{X}, \mathrm{Y}$, and I along the entire valve face, besides those with a round outline. This group includes, for example, C. himalaspera Jüttner \& Van de Vijver, C. subhimalaspera Jüttner \& Van de Vijver, C. amelieana Van de Vijver \& Lange-Bert., C. peraspera
Krammer, C. peraspera var. colombiana Krammer \& Lange-Bert., C. halophila Krammer and C. neogena (Grunow) Krammer (Jüttner et al. 2010).

The Cymbella aspera group is rarely recorded to Brazil; only Metzeltin and Lange-Bertalot (1998) and Schuster et al. (2015) have cited it. Schuster et al. (2015) found it in a first-order stream with a small strip of riparian vegetation and adjacent areas with corn crop in Santa Catatina State. Here we describe and illustrate a new Cymbella species found in first- and second-order oligotrophic streams from Rio Grande do Sul State (Brazil) in areas that have not previously been the subject of diatom studies.

\section{MATERIAL AND METHODS}

The first-, second- and third-order streams studied are situated in southern Brazil on a hillside of the Serra do Sudeste, São Lourenço do Sul city, in Rio Grande do Sul State (Fig. 1). The locality is a small village called Picada das Antas with dozens of farms. The stream drained into a forested watershed where angiosperms including Campomanesia xanthocarpa O. Berg, Trichilia clausenii C.DC., Casearia sylvestris Sw. and 


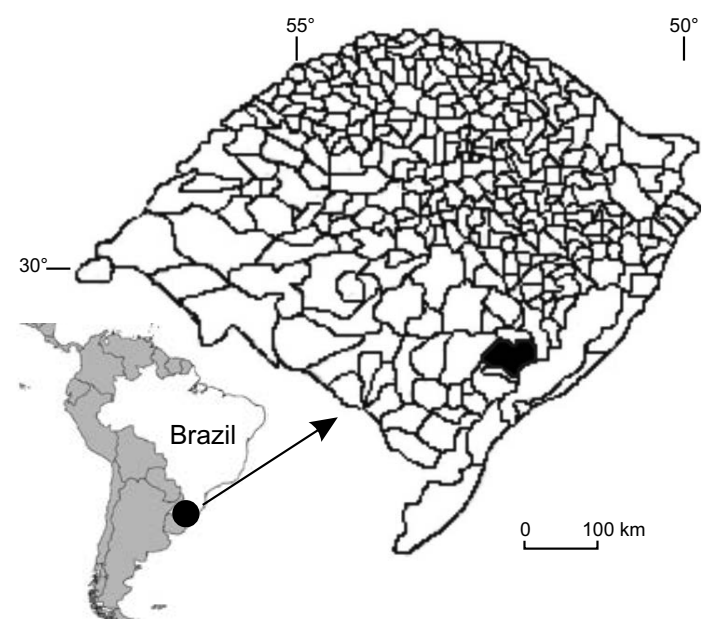

Fig 1. Study area in southern Brazil.

Cupania vernalis Cambess., and the gymnosperm Podocarpus lambertii Klotzsch ex Endl. along with the fern Dicksonia sellowiana Hook. are common (Figs 2 \& 3). The surrounding area is $50-70 \mathrm{~m}$ above sea level and formed by hills and valleys. Pelotas presents a humid subtropical climate (Cfa in Köppen-Geiger classification) with four distinctive seasons. The average temperature is $18^{\circ} \mathrm{C}$ and annual precipitation averages $1378 \mathrm{~mm}$ (http://en.climate-data.org/region/187).

On six separate dates we sampled at five sites located $2 \mathrm{~km}$ apart (Table 1), described as follows:

$1-31^{\circ} 39^{\prime} 42^{\prime \prime} \mathrm{S}, 52^{\circ} 13^{\prime} 34.5^{\prime \prime} \mathrm{W}-$ located in a firstorder stream in a farm, next to its head and forested watershed with Campomanesia xanthocarpa, Podocarpus lambertii, Trichilia clausenii, and Dicksonia sellowiana.

$2-31^{\circ} 19^{\prime} 33.9^{\prime \prime} \mathrm{S}, 52^{\circ} 13^{\prime} 57.9^{\prime \prime} \mathrm{W}$ - located in a secondorder stream next to the main house of the farm and a small henhouse. Part of the native forest had been removed and fruit trees including orange, persimmon and lemon trees grew there.

$3-31^{\circ} 19^{\prime} 47.5^{\prime \prime} \mathrm{S}, 52^{\circ} 14^{\prime} 07.1^{\prime \prime} \mathrm{W}$ - located in the same second-order stream as sampling site 2 , at a neighboring farm, where it is a third-order stream. Cattle breeding takes place there. Very few trees (e.g., Salix humboldtiana Willd.) occur along the stream margin.

$4-31^{\circ} 20^{\prime} 01.1^{\prime \prime} \mathrm{S}, 52^{\circ} 14^{\prime} 02.6^{\prime \prime} \mathrm{W}$ - located in another first-order stream $1.5 \mathrm{~km}$ away from the first site. The vegetation observed contained Trichilia clausenii, Casearia sylvestris and Cupania vernalis.

$5-31^{\circ} 20^{\prime} 29.0^{\prime \prime} \mathrm{S}, 52^{\circ} 14^{\prime} 12.6^{\prime \prime} \mathrm{W}$ - located in a thirdorder stream next to a bridge. The vegetation was mainly Salix humboldtiana.

The stream beds are composed of sand, cobbles and pebbles, of sandstone and granite origin. The cobbles and small boulders were scraped with a toothbrush, and surface sediment from the bottom was sampled with a pipette. We collected two samples from each sampling site between January 2010 and May 2014. One of the two samples was kept alive and the other was preserved in flasks with $4 \%$ formalin. In total, 23 sediment samples were collected during the studied period.

Fresh material of all samples was observed by LM to check for the presence of plastids in the diatoms. An aliquot of $1 \mathrm{~mL}$ was removed from the bottles and the organic matter in the cells was removed using equal amounts of $\mathrm{KMnO}_{4}$ and $\mathrm{HCl}$ in a water bath at $\mathrm{ca} 70^{\circ} \mathrm{C}$ until the sample became clear. The sample was then rinsed five times with bidistilled water until it was acidfree (Simonsen 1974). Part of the material was mounted in Naphrax ${ }^{\circledR}$ (Brunel Microscopes Ltd., Chippenham, Wiltshire, UK) and examined with a light microscope (LM-BX40, Olympus, Tokyo) equipped with a digital camera (OPT14000, Plustek, Taipei).

Table 1. Sampling sites and their respective environmental data during the studied period.

\begin{tabular}{lccccc}
\hline $\begin{array}{l}\text { Location/ } \\
\text { Environmental variable }\end{array}$ & $\begin{array}{c}(1)^{*} \\
\text { First-order } \\
\text { stream 1 }\end{array}$ & $\begin{array}{c}(2) \\
\text { Second-order } \\
\text { stream 1 }\end{array}$ & $\begin{array}{c}(3) \\
\text { Second-order } \\
\text { stream 2 }\end{array}$ & $\begin{array}{c}(4) \\
\text { First-order } \\
\text { stream 2 }\end{array}$ & $\begin{array}{c}(5) \\
\text { Third-order } \\
\text { stream }\end{array}$ \\
\hline $\mathrm{pH}$ & $7.00-7.93$ & $7.41-7.84$ & $7.44-7.84$ & $7.26-7.76$ & $7.26-7.70$ \\
Temperature & $19-21.5$ & $20-26.3$ & $20-26.3$ & $19-24.6$ & $21-27$ \\
Conductivity $\left(\mu{\left.\mathrm{S} . \mathrm{cm}^{-1}\right)}_{\text {Width }(\mathrm{m})}\right.$ & $78-95$ & $74-80$ & $80-104$ & $73-94$ & $90-105$ \\
Altitude $(\mathrm{m})$ & $0.2-0.4$ & $0.8-1.2$ & $2.0-5.0$ & $0.2-0.5$ & $4.0-5.0$ \\
\hline
\end{tabular}

${ }^{*}$ Parenthesized numbers match the sequence of sites given in Material and Methods. 

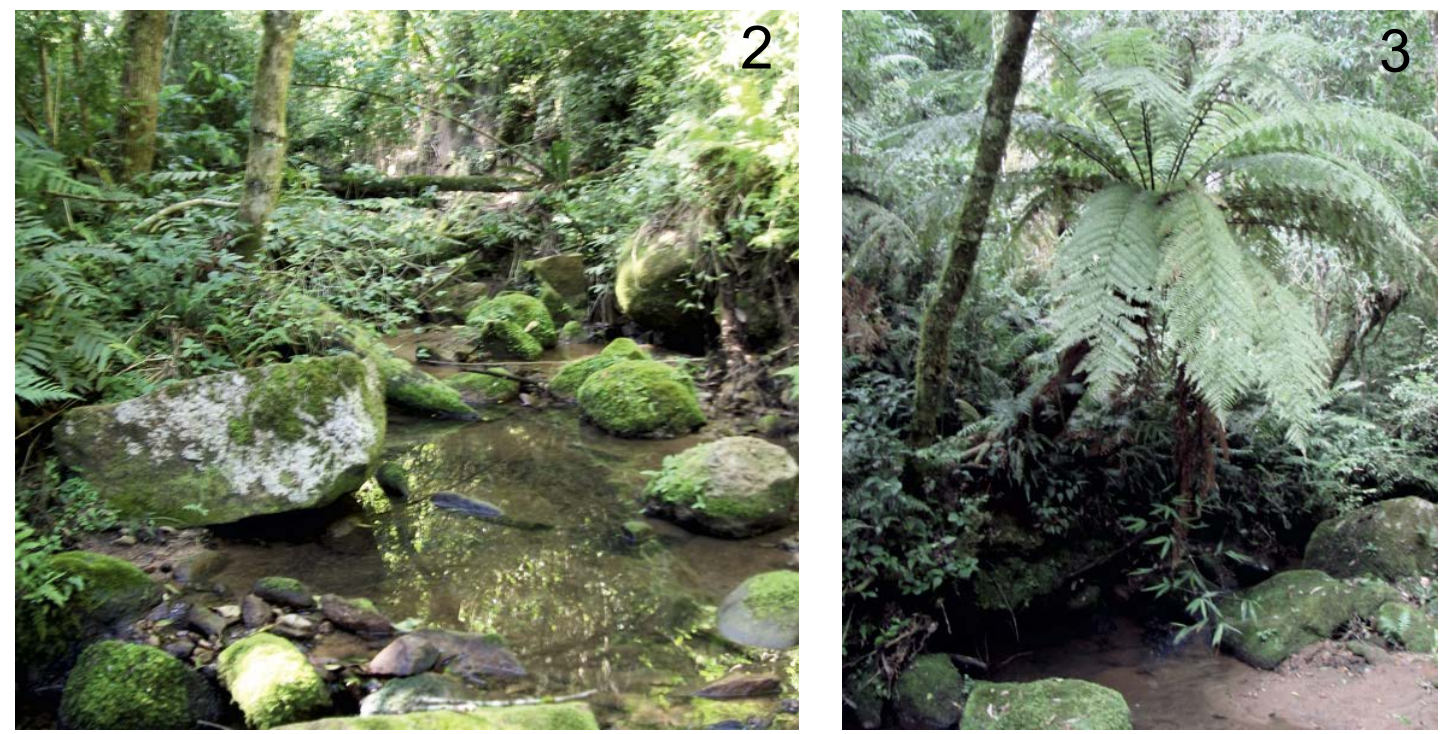

Figs 2 \& 3. Images from type locality. 3 -Dicksonia sellowiana Hook. present at type locality. Picada das Antas, São Lourenço do Sul, Rio Grande do Sul State, Brazil.

At least two permanent slides were prepared for each collected sample. At $1000 \times$ with oil immersion, 400 valves per slide were examined and counted. After this, the whole coverslip area was scanned at $200 \times$ in order to check for the presence of rare species, including Cymbella species.

For scanning electron microscopy (SEM), cleaned specimens were dried on a stub and then coated with platinum at $40 \mathrm{~mA}$ for 100 seconds using a Denton Vacuum Desk V sputter coater. The stubs were observed using a JEOL (JSM 6610LV, JEOL, Tokyo) microscope at accelerating voltage of $15-20 \mathrm{kV}$. The working distance was 9-11 mm.

Water temperature, $\mathrm{pH}$ and conductivity were measured at the sampling sites with a LUTRON pH-206 and a Hanna DiST Condutivimeter.

Raw samples are deposited in PEL (Pelotas) under accession numbers 24213 to 24219 . Terminology follows Van De Vijver and Lange-Bertalot (2008) and Jüttner et al. (2010).

\section{RESULTS}

We studied 33 valves by SEM and 55 by LM in order to describe Cymbella loescherae M. Garcia \& D. B. Dutra as a new species. Cymbella loescherae was observed alive in all samples of fresh material studied.
Cymbella loescherae M. Garcia \& D. B. Dutra, sp. nov.

Figs 4-21

Type locality: BRAZIL, Rio Grande do Sul State, São Lourenço do Sul, Picada das Antas, $31^{\circ} 39^{\prime} 42^{\prime \prime} \mathrm{S}, 52^{\circ} 13^{\prime} 34.5^{\prime \prime} \mathrm{W}$, elev. ca $62 \mathrm{~m}$ a.s.1., leg. D.B. Dutra \& M. Garcia, 13 September 2013.

Holotype: ICN 187445 in ICN, Herbário do Instituto de Ciências Naturais, Departamento de Botânica, Universidade Federal do Rio Grande do Sul, Porto Alegre, Brasil (Figs 4-9).

PARATYPES: The raw sample PEL 24.213 in PEL, the herbariam of Universidade Federal de Pelotas, Pelotas (Brazil) and KRAM A-18 in the Department of Phycology, W. Szafer Institute of Botany, Polish Academy of Sciences, Kraków (Poland).

LM DESCRIPTION. Valves dorsiventral with convex dorsal margin gradually curved towards broadly rounded poles (Figs 4-8). Ventral margin almost straight, slightly inflated in central part. Length 117-170, width 24.2-28.0 $\mu \mathrm{m}$, length/ width ratio 4.2-5.6. Axial area linear and parallel to valve margin, expanded to ventral side of valve in elliptical, asymmetrical central area. Raphe moderately lateral. Proximal raphe endings widened (Fig. 4). Distal raphe endings deflected 


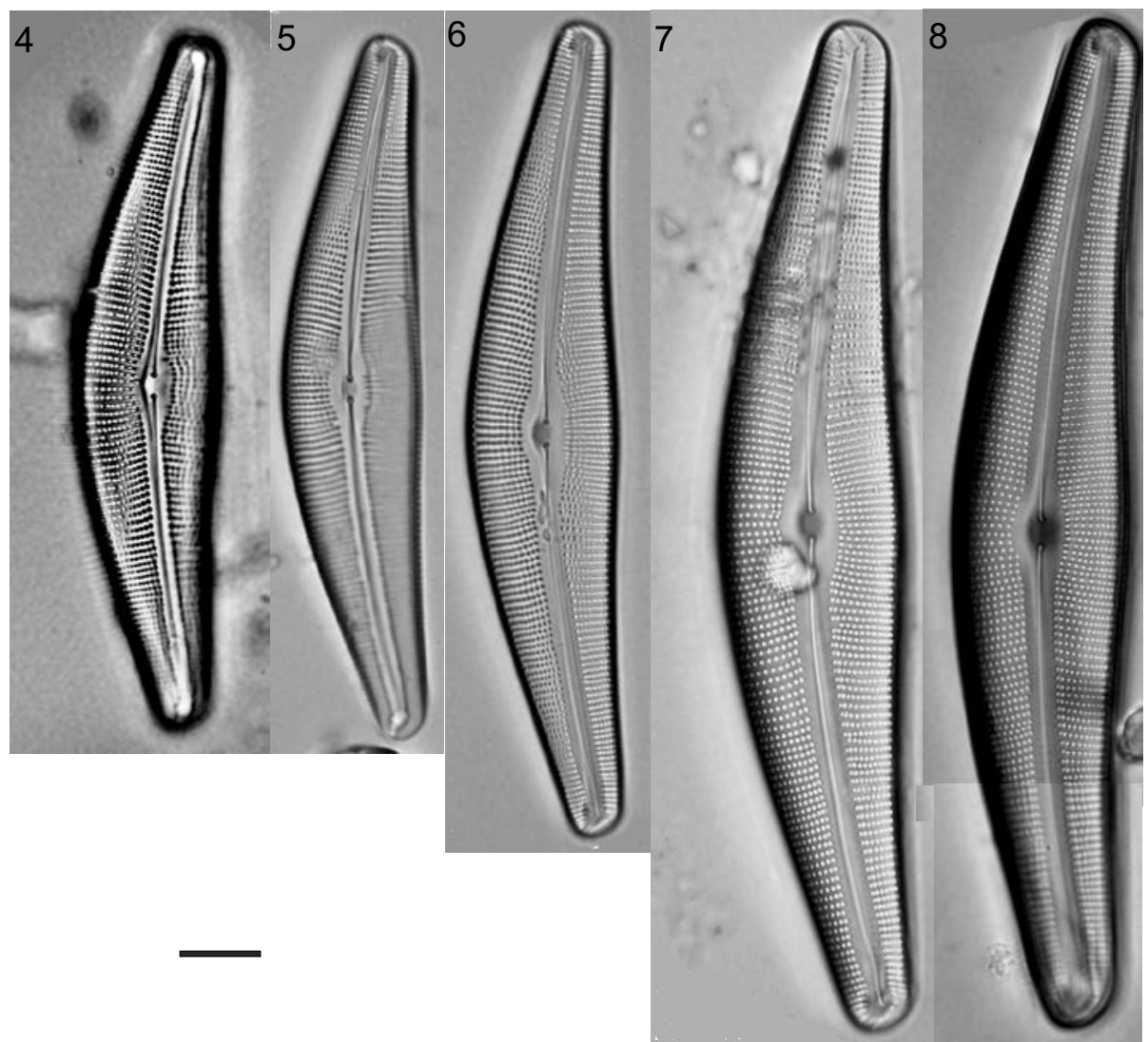

Figs 4-8. Whole valves of Cymbella loescherae M. Garcia \& D. B. Dutra, sp. nov. in LM (holotype slide). Scale bar $=10 \mu \mathrm{m}$.

to dorsal side of valve. Dorsal striae radiate and slightly curved, $8-10$ in $10 \mu \mathrm{m}$, areolae visible, $10-12$ in $10 \mu \mathrm{m}$. Stigmata in line and formed by large pores on ventral side next to expansion of central area, and almost indistinct from areolae.
SEM DESCRIPTION. External raphe slit rectilinear and sometimes undulated at poles and located on slightly elevated rib formed by thickened part of axial and central areas (Fig. 10). Proximal raphe endings form short drop-like shape and are

Table 2. Number of valves of Cymbella loescherae M. Garcia \& D. B. Dutra, sp. nov. counted with whole coverslip scanning.

\begin{tabular}{lccccc}
\hline $\begin{array}{l}\text { Locations/ } \\
\text { Sampling date }\end{array}$ & $\begin{array}{c}(1) \\
\text { First-order } \\
\text { stream 1 }\end{array}$ & $\begin{array}{c}(2) \\
\text { Second-order } \\
\text { stream 1 }\end{array}$ & $\begin{array}{c}\text { Third-order } \\
\text { stream 1 }\end{array}$ & $\begin{array}{c}(4) \\
\text { First-order } \\
\text { stream 2 }\end{array}$ & $\begin{array}{c}\text { (5) } \\
\text { Third-order } \\
\text { stream 2 }\end{array}$ \\
\hline January 2010 & 1 & $*$ & $*$ & $*$ & $*$ \\
August 2012 & 18 & 2 & $*$ & $*$ & $*$ \\
November 2012 & 2 & 28 & 4 & 20 & Not observed \\
March 2013 & 6 & 8 & Not observed & 2 & Not observed \\
September 2013 & 36 & 10 & Not observed & Not observed & Not observed \\
May 2014 & 1 & 1 & 2 & 1 & 2 \\
\hline
\end{tabular}

* Samples were not collected on those dates. 


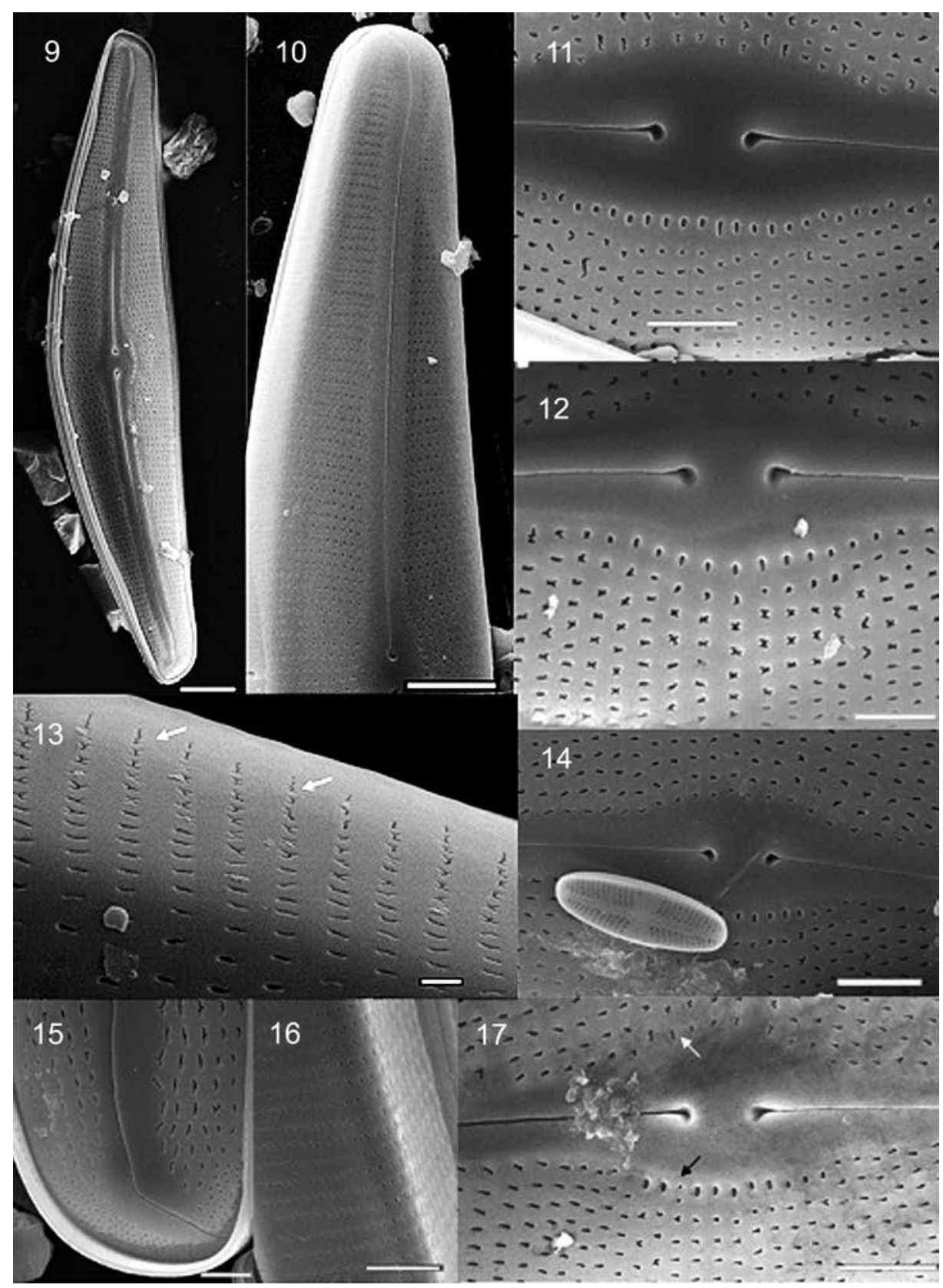

Figs 9-17. External views of Cymbella loescherae M. Garcia \& D. B. Dutra, sp. nov. in SEM 9 - External general view of frustule. 7 - Part of valve showing distal raphe bent dorsally. $11 \& 12$ - Central area with areolae in X, Y, I and zig-zag shapes on both dorsal and ventral valve sides. Note also the elliptical and round shape of stigmata. 13 - Detail of mantle showing the presence of areolae with X, Y and zig-zag shapes (indicated) next to mantle margin. 14 - Detail of another central area with areolae in X, Y and I shapes. Note raphe proximal ends slightly deflected to ventral side. 15 - Apex in detail showing large apical pore field and I- and flying-bird-shaped areolae. 16 - Mantle and valve face step with I-shaped areolae only. 17 - Detail of another valve center with areolae in X, Y, I and zig-zag shapes (white arrow) and one stigma subdivided in two (black arrow). Scales bars: $9 \& 10=10 \mu \mathrm{m} ; 11,12,14,16 \& 17=5 \mu \mathrm{m} ; 15=2 \mu \mathrm{m} ; 13=1 \mu \mathrm{m}$. 


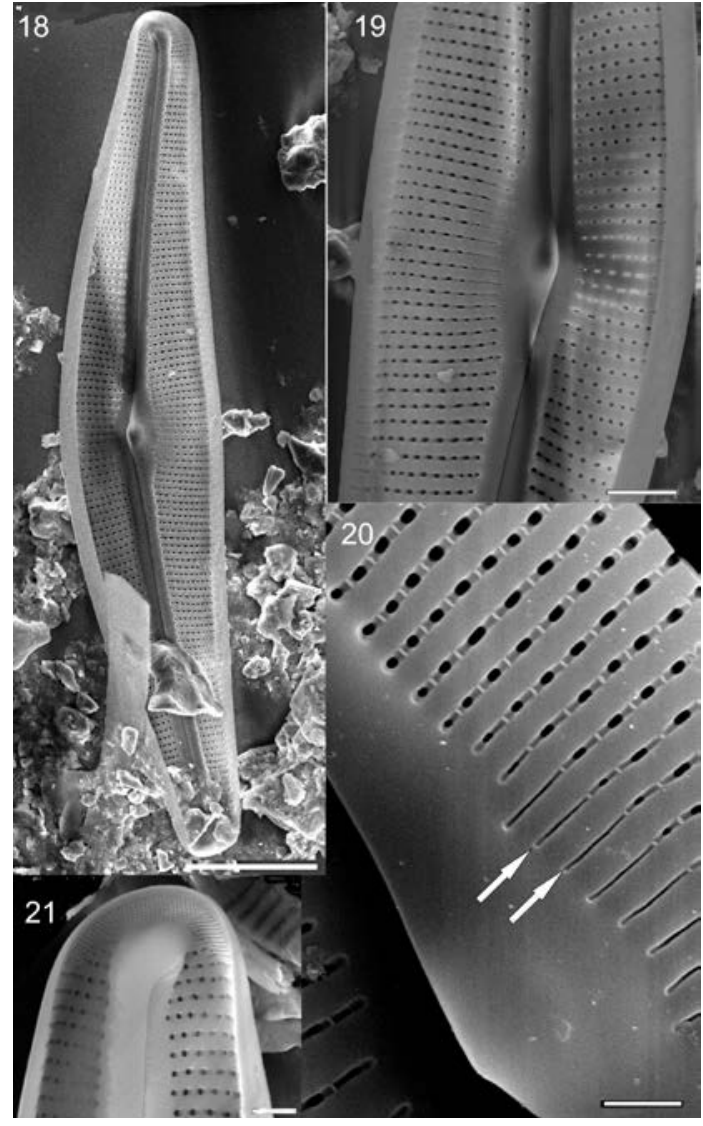

Figs 18-21. SEM of internal views of Cymbella loescherae M. Garcia \& D. B. Dutra, sp. nov. 18 - General internal view of valve. 19 - Central part of valve in internal view. 20 - Detail of apex. 21 - Central area showing long internal opening of stigmata (white arrows) and alveoli delimited by two struts. Note areolae internal opening in elliptical shape. Scales bars: $18 \& 19=5 \mu \mathrm{m} ; 20 \& 21=2 \mu \mathrm{m}$.

slightly deflected ventrally (Figs 11, 12, 14 \& 17); distal raphe endings abruptly deflect dorsally (Figs $10 \& 15)$. Large apical pore fields formed by small pores organized in rows (Fig. 21). Areolae apically oriented and stigmata transapically oriented (Figs 15 \& 20). Areolae I-, X- and Y-shaped on central part of valve face (Figs 11, 12, 14 \& 17), in I, X, Y and zig-zag shapes on mantle (Figs 13 \& 16), and I and flying-bird shapes next to valve face apices (Fig. 15). Stigmata round, mainly slightly elongated and transapically oriented, numbering 9-14 on ventral side of valve next to central nodule. Very rarely subdivided into 2 small round stigmata (Fig. 17). Internally, between striae, large costae limiting rectangular alveoli separated by silica struts (Figs $18 \& 21$ ). Elliptical internal areolae opening inside alveoli (Figs 19 \& 21). Stigmata alveoli found in narrow furrow (Fig. 21).

Etymology. Named to honor Waldemar Loescher (19 August 1935 - 11 November 2013) and his family, for their commitment to native forest preservation in Picada das Antas, São Lourenço do Sul city, Rio Grande do Sul State, Brazil.

Distribution. The distribution of Cymbella loescherae in the study area indicates that it is rather more frequent in first- and second-order streams, where the natural vegetation is better preserved, water $\mathrm{pH}$ ranges from 7.0 to 7.9 and conductivity between 73 and $95 \mu \mathrm{S} \cdot \mathrm{cm}^{-1}$ (Tables $1 \& 2)$. The distribution pattern observed at the studied sites may indicate it is becoming rarer in places subject to higher anthropopression, but more studies are needed to assess its ecological preferences.

ECOLOGy. Cymbella loescherae was observed alive in all unprepared samples. It was never found during 400-valve counts, but while scanning whole coverslips, several valves were observed and enumerated as presented in Table 2 .

Cymbella loescherae was the largest Cymbella found in the samples. It was frequently found in samples from bottom sediment, cobbles and pebbles. In the same samples, common diatoms were Adlafia drouetiana (R. Patrick) Metzeltin \& Lange-Bert., Navicula asymmetrica Cleve, Nupela praecipua (E. Reichardt) E. Reichardt (abundant only at site 1) and Achnanthidium minutissimum (Kütz.) Czarn. The two first species listed were described in the first part of the $20^{\text {th }}$ century by Patrick (1944) from streams in the northeast of Rio Grande do Sul State.

\section{DisCUSSION}

Stigma morphology presents interesting and significant differences in the Cymbella aspera group. In $C$. subhimalaspera the stigmata are 1-3 times longer than the areolae, and in $C$. peraspera var. colombiana the stigmata are fine undulated slits about the same size as the areolae. Cymbella 


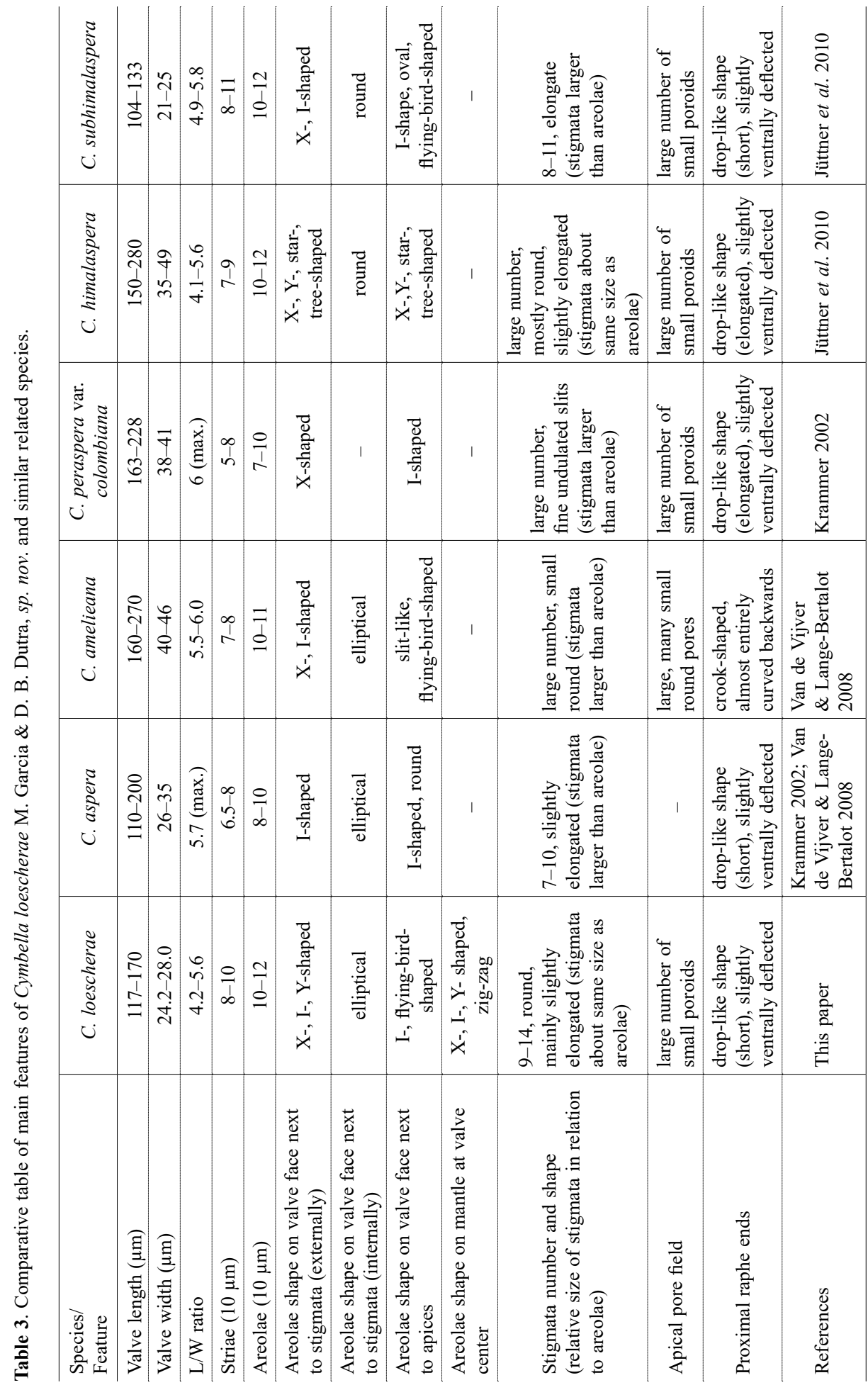


aspera and C. amelieana have stigmata larger than the areolae; C. lanceolata (C. Agardh) C. Agardh, on the other hand, has areolae larger than the stigmata (Van De Vijver \& Lange-Bertalot 2008). In C. subhimalaspera they are larger than the areolae, while in $C$. himalaspera they appear to have areolae and stigmata of about the same size, as does C. loescherae (Table 3).

The shape of the areolae at the valve center, especially on the ventral side next to the stigmata, is an important character to distinguish species in the $C$. aspera group. Cymbella himalaspera is the species with higher diversity of areola shapes at the valve center.

Regardless of the form of the external openings of areolae, all present about the same morphology internally, and the internal areolae openings are distinct in the species of the $C$. aspera group. Cymbella himalaspera and C. subhimalaspera present the smallest ones (Jüttner et al. 2010), mainly round in shape, while in other species the internal openings are elliptical, occupying a larger area in the alveolus, as in C. amelieana, C. aspera and $C$. loescherae.

The species most similar to $C$. loescherae is C. subhimalaspera: both present about the same metric data set and have drop-like external proximal raphe endings which are slightly curved to the ventral side, although they are short drop-like in the former and elongated drop-like in the latter, and their external openings of the areolae show a distinct morphology. The most critical differences are in the shape of the stigmata, which are longer in C. subhimalaspera than in C. loescherae; this difference is associated with the high number of stigmata (9-14) in the latter. The number of subdivided stigmata also seems to be higher in C. subhimalaspera. Only one specimen illustrated in our Figure 19 presented such a feature. Furthermore, the areolae internal openings are elliptical in C. loescherae and round in C. subhimalaspera.

\section{CONCLUSIONS}

The new species belongs to the $C$. aspera group described by Krammer (2002) and Jüttner et al. (2010), characterized by areolae with a distinct morphology and a large apical pore field formed by very small round pores externally, and internally by robust costae, alveoli with struts, and 6 or more stigmata alveoli. The stigmata are slightly elongated, the areolae are round and small, and the proximal raphe endings are in long drop-like form.

Cymbella loescherae differs from the remaining species assembled in the $C$. aspera group by a group of distinctive features including the short elliptical shape of the stigmata, the elliptical internal areolae openings, and the diverse shapes of the areolae (X, I, Y, zig-zag), which are mainly located at the valve center on the dorsal and ventral sides.

The distribution in the study area suggests that Cymbella loescherae is rather more frequent at sites where the natural vegetation is better preserved (Tables $1 \& 2$ ). These results point to the need for more studies in such countryside areas. Its presence, even when rare, can serve as an indicator.

Cymbella loescherae is a peculiar species in well-preserved areas in the south of Brazil, found mainly in some first- and second-order streams (5 collecting stations) during four years of study. Its distribution is in accord with findings from other authors such as Van De Vijver and LangeBertalot (2008) and Jüttner et al. (2010), who have described large new Cymbella species from wellpreserved areas of the world.

ACKNOWLEDGEMENTS. The SEM images were taken in the Electron Microscopy Center (CEME-Sul, FURG, Rio Grande) with the technical assistance of Dr. Eonice Soares de Lacerda, Dr. Rudmar R. Krunreick and Dr. Erica Silva Silveira. We are grateful to Dr. Ingrid Jüttner for comments on the species when we first found it, and to Luciana Loescher for graciously hosting our visits to the Moinho Loescher farm. We thank the anonymous reviewers for helpful comments and suggestions.

\section{REFERENCES}

Fourtanier E. \& Kociolek J. P. 2011. Catalogue of Diatom Names. California Academy of Sciences. [10 June 2016]. http://researcharchive.calacademy.org/research/diatoms/ names/.

Jüttner I., Gurung S., Sharma C., Sharma S. De HaAn M. \& VAN DE ViJVER B. 2010. Morphology of new taxa in the 
Cymbella aspera and Cymbella neocistula groups, Cymbella yakii sp. nov., and Cymbella cf. hantzschiana from Everest National Park, Nepal. Polish Bot. J. 55: 73-92.

Krammer K. 2002. Cymbella. In: H. Lange-Bertalot (ed.), Diatoms of Europe. 3: 1-584. A.R.G. Gantner Verlag K.G., Ruggell.

Metzeltin D. \& Lange-Bertalot H. 1998. Tropical diatoms of South America I: About 700 predominantly rarely known or new taxa representative of the neotropical flora. Iconogr. Diatomol. 5: 1-695.

Patrick R. 1944. Estudo limnológico e biológico das lagoas da região litoranea sul-riograndense. II. Some new dia- toms from the Lagoa dos Quadros. Bol. Mus. Nac. Rio de Janeiro, Bot. 2: 1-6.

Schuster K. F., Tremarin P. I. \& Souza-Franco G. M. 2015. Alpha and beta diversity of phytoplankton in two subtropical eutrophic streams in southern Brazil. Acta Bot. Bras. 29: 597-607.

SIMONSEN R. 1974. The diatom plankton of the Indian Ocean Expedition of R/V "Meteor". Meteor Forschungsergebn., D 19: 1-107.

Van De Vijver B. \& Lange-Bertalot H. 2008. Cymbella amelieana sp. nov., a new large Cymbella species from Swedish rivers. Diatom Res. 23: 511-518. 